\title{
PEMANFAATAN DATA SATELIT HIMAWARI-8 SERTA DATA CURAH HUJAN DAN HARI HUJAN BULANAN DALAM ANALISIS KEJADIAN BANJIR KOTA PADANG, 9 SEPTEMBER 2017 DAN 26 SEPTEMBER 2018
}

\author{
Vinca Amalia Rizkiafama*, Tesla Kadar Dzikiro, Agus Safril \\ Program Studi Klimatologi, Sekolah Tinggi Meteorologi Klimatologi dan Geofisika, \\ Jl. Perhubungan I No.5 Pondok Betung, Pondok Aren, Tangerang Selatan \\ Email : *amaliavinca987@gmail.com
}

\begin{abstract}
Flood events on Wednesday, September 26, 2018 in several sub-districts in the city of Padang showed different conditions with the Indonesian region in general which were in normal to drier conditions. One year earlier, precisely on September 9, 2017 there were floods in almost all areas of the city of Padang. This study aims to determine the atmospheric conditions during flood events from the climatological and meteorological side. The data used are monthly rainfall and monthly number of Rainy Days (HH) from 1981-2018 from the Minangkabau Meteorological Station, as well as Himawari-8 Weather Satellite data. Satellite data is processed using Satellite Animation and Interactive Diagnosis (SATAID) software to obtain cloud cover analysis, cloud growth activities, and atmospheric lability levels. September 2017 and September 2018 are in the nature of normal rain with a percentage of $101 \%$ and $88 \%$. The increase in the amount of rainfall in August 2017 to September 2017 is not significant at $27 \mathrm{~mm}$ compared to August 2018 to September 2018 which is significant at $148 \mathrm{~mm}$. The number of rainy days in September 2017 and 2018 were 24 and 23 respectively, which showed that almost every day there was rain in those months. Meteorological analysis shows that there is convective cloud growth activity in the Padang area which is characterized by an unstable level of atmospheric stability which has the potential for moderate to heavy rainfall.
\end{abstract}

Keywords: flood, precipitation, rain day, Himawari-8

\begin{abstract}
Abstrak: Kejadian banjir pada Rabu, 26 September 2018 di beberapa kecamatan di Kota Padang menunjukkan kondisi yang berlainan dengan wilayah Indonesia pada umumnya yang berada dalam kondisi normal hingga lebih kering. Satu tahun sebelumnya, tepatnya pada 9 September 2017 juga terjadi banjir hampir di seluruh wilayah Kota Padang. Penelitian ini bertujuan untuk mengetahui kondisi atmosfer pada saat kejadian banjir dari sisi klimatologis dan meteorologisnya. Data yang digunakan adalah curah hujan bulanan dan jumlah Hari Hujan (HH) bulanan dari tahun 1981-2018 dari Stasiun Meteorologi Minangkabau, serta data Satelit Cuaca Himawari-8. Data satelit diolah menggunakan piranti lunak Satellite Animation and Interactive Diagnosis (SATAID) untuk mendapatkan analisis tutupan awan, aktivitas pertumbuhan awannya, dan tingkat labilitas atmosfer. September 2017 dan September 2018 berada pada sifat hujan normal dengan presentase 101\% dan 88\%. Peningkatan jumlah curah hujan bulan Agustus 2017 ke September 2017 tidak signifikan yaitu sebesar 27 mm dibandingkan Agustus 2018 ke September 2018 yang signifikan yaitu sebesar $148 \mathrm{~mm}$. Jumlah hari hujan di bulan September 2017 dan 2018 berturut-turut sebesar 24 dan 23 yang menunjukkan bahwa hampir setiap hari terjadi hujan di bulan-bulan tersebut. Analisis secara meteorologis menunjukkan bahwa terdapat aktivitas pertumbuhan awan konvektif di daerah Padang yang ditandai dengan tingkat stabilitas atmosfer yang labil sehingga berpotensi terjadinya hujan sedang hingga lebat.
\end{abstract}

Kata kunci: banjir, curah hujan, hari hujan, Himawari-8 


\section{PENDAHULUAN}

Peta analisis sifat hujan bulan September 2018 dari Badan Meteorologi Klimatologi dan Geofisika (BMKG) menjelaskan bahwa hampir seluruh wilayah Indonesia mendapatkan pengurangan jumlah curah hujan dari normalnya yang diindikasikan dengan sifat hujan yang berada pada bawah normal. Kondisi tersebut juga dijelaskan dengan peta analisis curah hujan bulan September 2018 yang menunjukkan bahwa curah hujan berada pada kategori rendah hampir di seluruh wilayah Indonesia. Salah satu wilayah di Indonesia yang berlainan dengan kondisi kering tersebut adalah Sumatera Barat. Wilayah tersebut berada pada sifat hujan atas normal yang mendapatkan curah hujan lebih tinggi hingga 200\% dari normalnya. Curah hujan bulan September 2018 di Sumatera Barat dikategorikan pada curah hujan menengah hingga tinggi yaitu 200 sampai $400 \mathrm{~mm}$ per bulan.

Stasiun Meteorologi Minangkabau, Padang mencatat jumlah curah hujan dalam satu hari yaitu $31 \mathrm{~mm}$ pada tanggal 26 September 2018. Menurut laman okezone.com, pada waktu yang bersamaan terjadi banjir di Kota Padang tepatnya pada Kecamatan Lubuk Kilangan, Kecamatan Lubuk Begalung, dan Kecamatan Padang Selatan. Faktor meteorologi utama yang menyebabkan banjir adalah curah hujan. Jumlah curah hujan yang sama mungkin menyebabkan banjir di tempat yang satu tetapi belum tentu di tempat lain (Tjasyono, 2012). Kategori intensitas curah hujan di Indonesia menurut BMKG dibagi menjadi empat, yaitu kategori ringan bila curah hujan 1-5 mm/jam atau 5-20 mm/hari, kategori sedang 5-10 $\mathrm{mm} / \mathrm{jam}$ atau $20-50 \mathrm{~mm} /$ hari, kategori lebat jika curah hujan $10-20 \mathrm{~mm} / \mathrm{jam}$ atau $50-100$ $\mathrm{mm} /$ hari, dan sangat lebat bila curah hujan lebih dari $20 \mathrm{~mm} / \mathrm{jam}$ atau $100 \mathrm{~mm} / \mathrm{hari}$. Banjir yang terjadi pada akhir September 2018 di Padang disebabkan oleh curah hujan dengan kategori sedang.

Satu tahun sebelumnya pada bulan yang sama, tepatnya pada tanggal 9 September 2017 Kota Padang juga mengalami banjir. Dilansir dari media elektronik ANTARA news, Badan Penanggulangan Bencana Daerah (BPBD) Kota Padang menjelaskan hampir seluruh wilayah kota terkena dampak banjir. Daerah dengan dampak banjir terparah adalah Arai Pinang dan By Pass. Stasiun Meteorologi Minangkabau, Padang mencatat jumlah curah dalam satu hari tersebut sebesar $95 \mathrm{~mm}$. Nilai tersebut termasuk sebagai hujan dengan intensitas lebat berdasarkan pengkategorian BMKG.

Kejadian banjir yang terjadi di bulan yang sama di dua tahun terakhir tersebut melatar belakangi penelitian ini untuk mengetahui kondisi atmosfer pada waktu kejadian berdasarkan sisi klimatologis maupun meteorologisnya. 


\section{METODE PENELITIAN}

\subsection{Lokasi Penelitian}

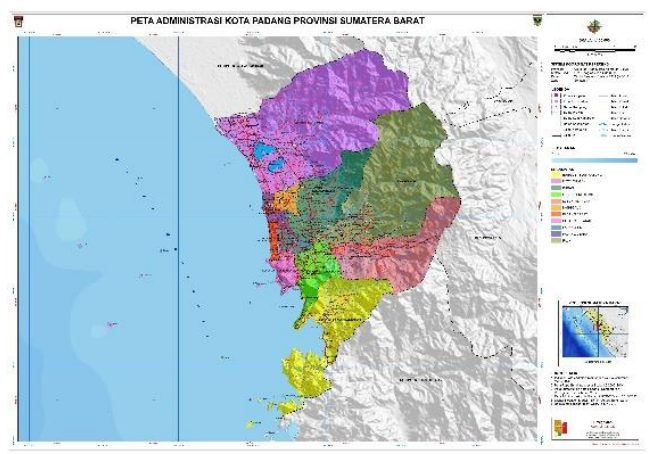

Gambar 1. Lokasi Penelitian (Sumber: Peta Tematik Indonesia)

Lokasi penelitian adalah Kota Padang dengan koordinat $00^{\circ} 44^{\prime} \mathrm{LS}-01^{\circ} 08^{\prime}$ LS dan $100^{\circ}$ $05^{\prime} \mathrm{BT}-100^{\circ} 34^{\prime} \mathrm{BT}$

\subsection{Data}

Penelitian ini menggunakan data parameter iklim yaitu curah hujan bulanan dan jumlah Hari Hujan (HH) bulanan dari tahun 1981 sampai dengan 2018. Hari hujan didefinisikan sebagai hari dengan jumlah curah hujan lebih dari $1 \mathrm{~mm}$ per hari. Data tersebut diperoleh dari Stasiun Meteorologi Minangkabau, Padang yang terletak pada titik koordinat $0,79^{\circ}$ LS dan $100,29^{\circ}$ BT. Kedua parameter tersebut digunakan untuk menghitung nilai normalnya dan kemudian dibandingkan nilai pada bulan kejadian dengan nilai normalnya.

Data yang selanjutnya adalah data citra satelit cuaca Himawari-8 kanal IR pada tanggal 9 September 2017 dan 26 September 2018. Data tersebut diperoleh dari Sub Bidang Pusat Pengelolaan Citra Satelit BMKG. Data tersebut digunakan untuk mengetahui tutupan awan dan stabilitas atmosfer di Padang.

\subsection{Metode}

Data curah hujan dan hari hujan diolah menggunakan piranti lunak Spread Sheet. Proses pengolahan digunakan untuk mencari nilai normal curah hujan bulanan dan normal jumlah hari hujan bulanan berdasarkan perhitungan nilai rata-ratanya dari tahun 1981 sampai 2010.

$$
\text { Normal CH bulanan Jan, Feb, ..., Des }=\frac{\sum_{1981}^{2010} \mathbf{C H} \text { bulanan }}{30}
$$

Nilai normal per bulan kemudian diolah menjadi grafik normal $\mathrm{CH}$ dari Januari hingga Desember untuk mendapatkan pola umumnya. Proses pengolahan selanjutnya adalah mencari sifat hujan pada bulan kejadian yaitu September 2017 dan September 2018. Perhitungan sifat hujan adalah sebagai berikut:

$$
\text { Sifat hujan bulanan }=\frac{\text { curah hujan bulanan }}{\text { normal curah hujan bulanan }} \times \mathbf{1 0 0} \%
$$

Hasil perhitungan di atas kemudian dikategorikan berdasarkan kategori sifat hujan BMKG sebagai berikut:

Atas Normal $(\mathrm{AN})=$ lebih dari $115 \%$

Normal $(\mathrm{N})=85 \%$ sampai $115 \%$ 
Bawah Normal $(\mathrm{BN})=$ kurang dari $85 \%$

Analisis mengenai jumlah hari hujan bulanan difokuskan pada bulan September 2017 dan September 2018 dan dibuat perbandingannya terhadap bulan September di tahun lainnya.

Satelit Himawari-8 adalah generasi baru satelit meteorologi geostasioner Jepang yang membawa sensor optik canggih dengan resolusi radiometrik, spektral, dan spasial yang jauh lebih tinggi daripada yang sebelumnya tersedia di orbit geostasioner. Himawari memiliki 16 band pengamatan, dan resolusi spasial sebesar 0,5 - $1 \mathrm{~km}$ untuk kanal visible dan $2 \mathrm{~km}$ untuk kanal inframerah (K Bessho, K Date, 2016). Data citra satelit diolah menggunakan piranti lunak Satellite Animation and Interactive Diagnosis (SATAID). Hal yang paling mendasar dari pengolahan citra satelit Himawari-8 dengan menggunakan aplikasi SATAID yaitu tenik menampilkan citra satelit sebagai indentifikasi awan dan teknik pemanfaatan data Numerical Weather Prediction (NWP) sebagai analisis unsur-unsur cuaca (Fadholi, 2013). Proses pengolahan digunakan untuk mengetahui tutupan awan dan stabilitas atmosfer di Kota Padang saat kejadian banjir 9 September 2017 dan 26 September 2018.

Untuk mengetahui pertumbuhan awan atau aktivitas konveksi awan, dilakukan analisis time series suhu puncak awan di Kota Padang. Dengan memanfaatkan Numerical Weather Prediction (NWP) pada satelit cuaca Himawari-8 maka akan menghasilkan data stabilitas atmosfer. Data tersebut dianalisis sesuai dengan masing - masing nilai indeks stabilitas atmosfer. Sehingga akan didapati stabilitas atmosfer dalam keadan stabil, labil atau normal yang mengindikasikan kuat atau lemahnya proses konveksi di Kota Padang.

Tabel 1. Interval Indeks Stabilitas Atmosfer untuk Wilayah Tropis (Budiarti et al., 2012)

\begin{tabular}{llll}
\hline Indeks & Lemah & Moderat & Kuat \\
\hline TT Index & $<42$ & $42-46$ & $>46$ \\
K Index & $<29$ & $29-37$ & $>37$ \\
SWEAT & $<135$ & $135-239$ & $>239$ \\
CAPE & $<1000$ & $1000-2500$ & $>2500$ \\
\hline
\end{tabular}

\section{HASIL DAN PEMBAHASAN}

\subsection{Normal Curah Hujan}

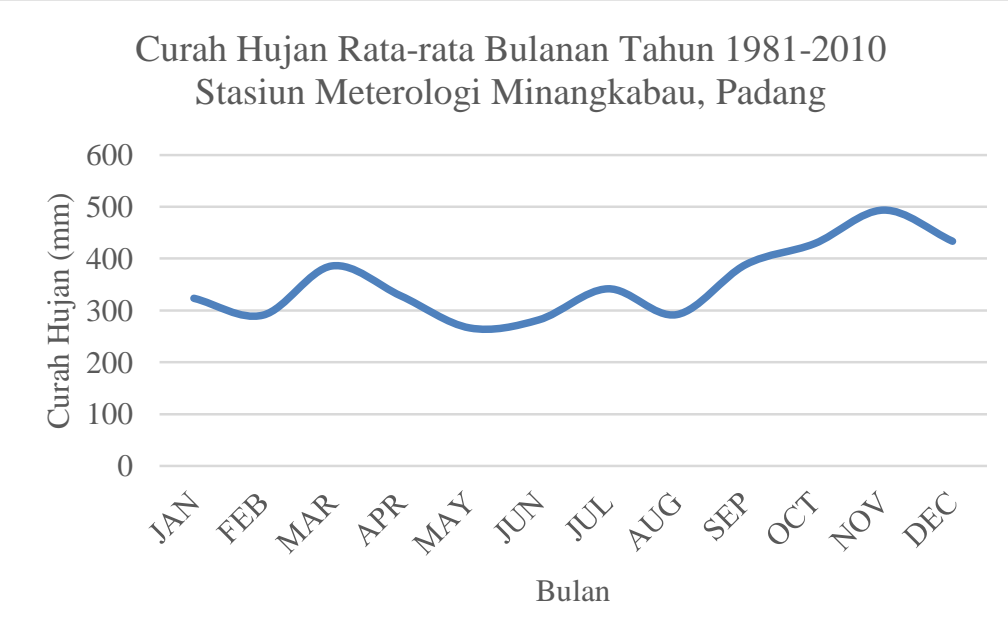

Gambar 2. Grafik Curah Hujan Rata-rata Bulanan Tahun 1981-2010 Stasiun Meteorologi Minangkabau, Padang 
Berdasarkan grafik di atas dapat diketahui pola hujan Kota Padang adalah ekuatorial. Wilayah tersebut dicirikan dengan curah hujan tinggi sepanjang tahun, yaitu lebih dari 150 $\mathrm{mm}$ per bulan. Wilayah dengan pola hujan ekuatorial memiliki dua puncak hujan yaitu pada bulan Oktober sampai November (ON) dan pada bulan Maret hingga Mei (MAM). Dua puncak tersebut dikaitkan dengan Inter Tropical Convergence Zone (ITCZ) (Davidson et al., 1984). Tidak ada alasan yang jelas mengapa puncak di ON jauh lebih tinggi daripada MAM. Ada kemungkinan pengaruh arus permukaan dingin yang datang dari utara keluar dari Cina Selatan Laut selama Januari-Maret (Wyrtki, 1961) yang menekan jumlah hujan.

Pola ekuatorial Kota Padang memiliki dua puncak hujan di bulan November dan Maret. Bulan kering untuk wilayah Padang adalah Januari hingga Februari (JB) dan Mei hingga Agustus (MJJA). Bulan Agustus menjadi bulan peralihan dari kondisi kering menuju lebih basah yang dimulai pada bulan September. Bulan Agustus juga menjadi bulan yang lebih kering dari periode kering sebelumnya yaitu Juli. Sedangkan, bulan September merupakan awal dari kondisi basah yang sebelumnya mengalami kondisi kering lebih lama daripada periode kering lainnya dalam satu tahun.

\subsection{Sifat Hujan September 2018 dan September 2017}

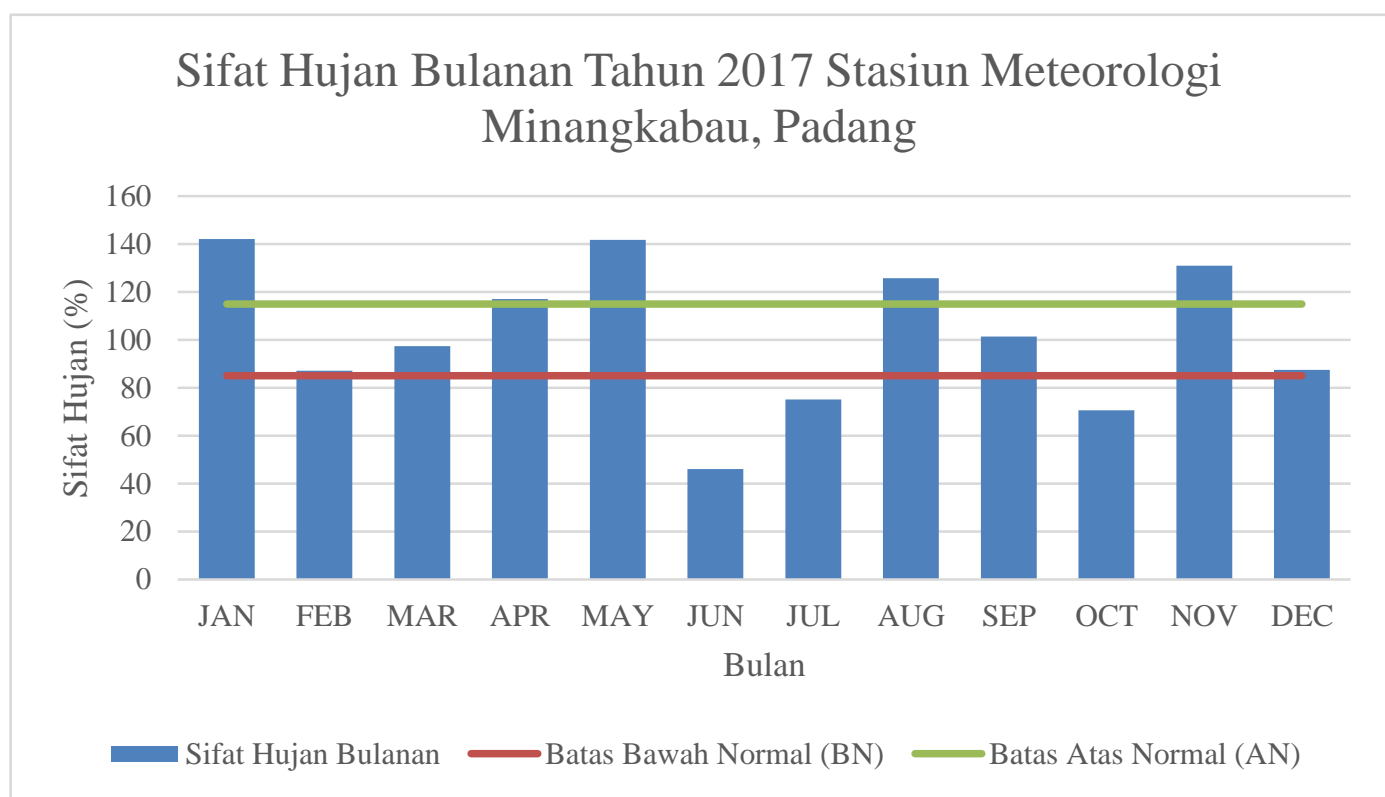

Gambar 3. Grafik Sifat Hujan Bulanan Tahun 2017 Stasiun Meteorologi Minangkabau, Padang

Perbandingan nilai curah hujan bulan September 2017 terhadap jumlah curah hujan normalnya pada bulan yang sama akan menghasilkan presentase sifat hujan bulan tersebut. Nilai tersebut menunjukkan bagaimana kondisi hujan pada bulan tersebut jika dilihat dari kondisi normalnya. September 2017 memiliki presentase sifat hujan 101\% dan termasuk dalam kondisi normal. Di bulan sebelumnya yaitu Agustus 2017 berada dalam kondisi atas normal yang mendapatkan tambahan curah hujan di bulan tersebut. Dalam pembahasan sebelumnya Agustus merupakan bulan kering dan kondisi peralihan menuju kondisi basah. Agustus 2017 menyebabakan wilayah Kota Padang yang umumnya mengalami kekurangan curah hujan menjadi kelebihan curah hujan. 


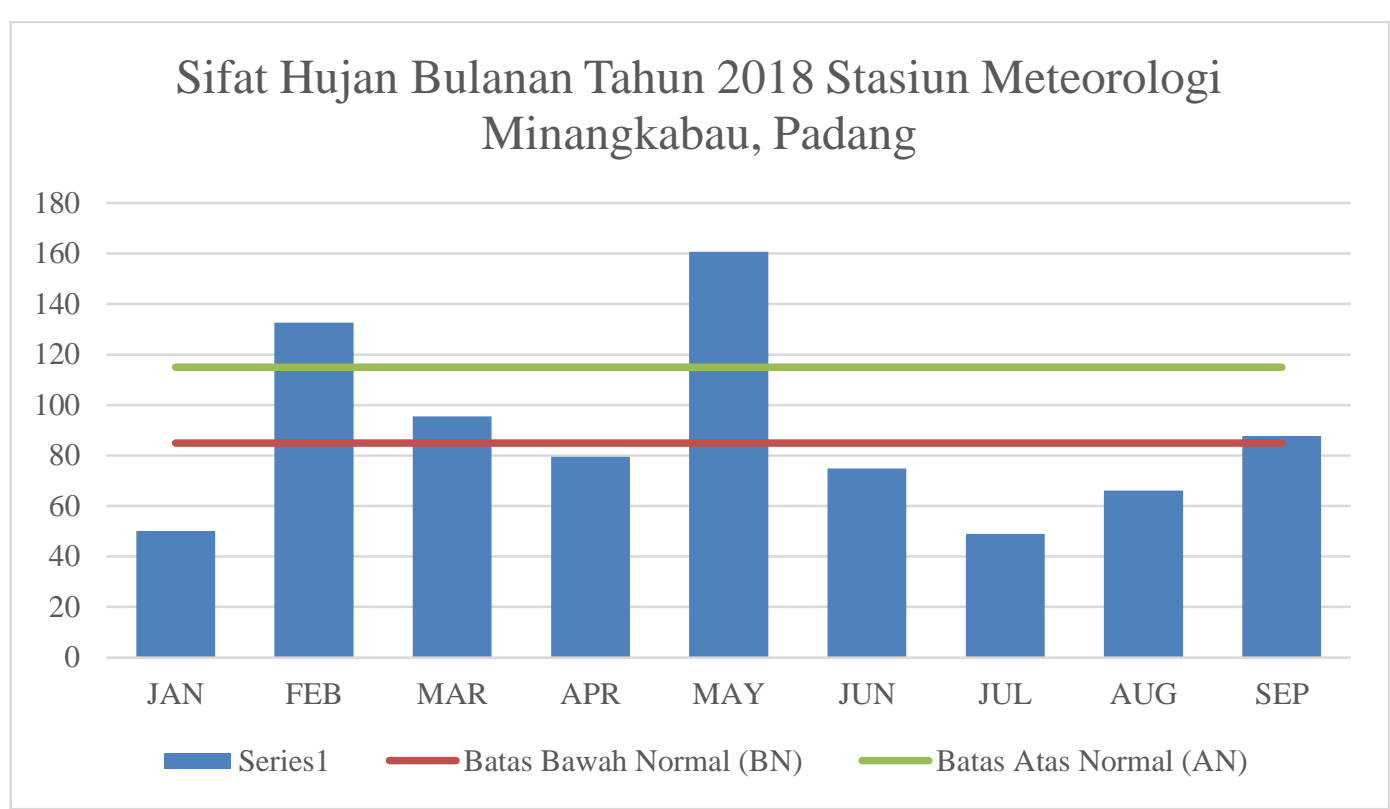

Gambar 4. Grafik Sifat Hujan Bulanan Tahun 2018 Stasiun Meteorologi Minangkabau, Padang

September 2018 memiliki presentase sifat hujan 88\% dan termasuk dalam kondisi normal. Di bulan sebelumnya yaitu Agustus 2018 berada dalam kondisi bawah normal sebesar 66\% yang mengalami pengurangan curah hujan di bulan tersebut. Di dua bulan sebelumnya yaitu Juni dan Juli 2018 juga mengalami pengurangan curah hujan dengan kategori sifat hujan di bawah normal. Kondisi lebih kering dari normalnya selama beberapa bulan menyebabkan dampak yang signifikan ketika terjadi hujan dengan intensitas sedang sampai lebat yaitu ketika hujan mulai turun dan mengubah sifat hujan menjadi normal pada bulan September 2018.

\subsection{Perbandingan Nilai Curah Hujan Bulanan di Tahun 2017 dan 2018}

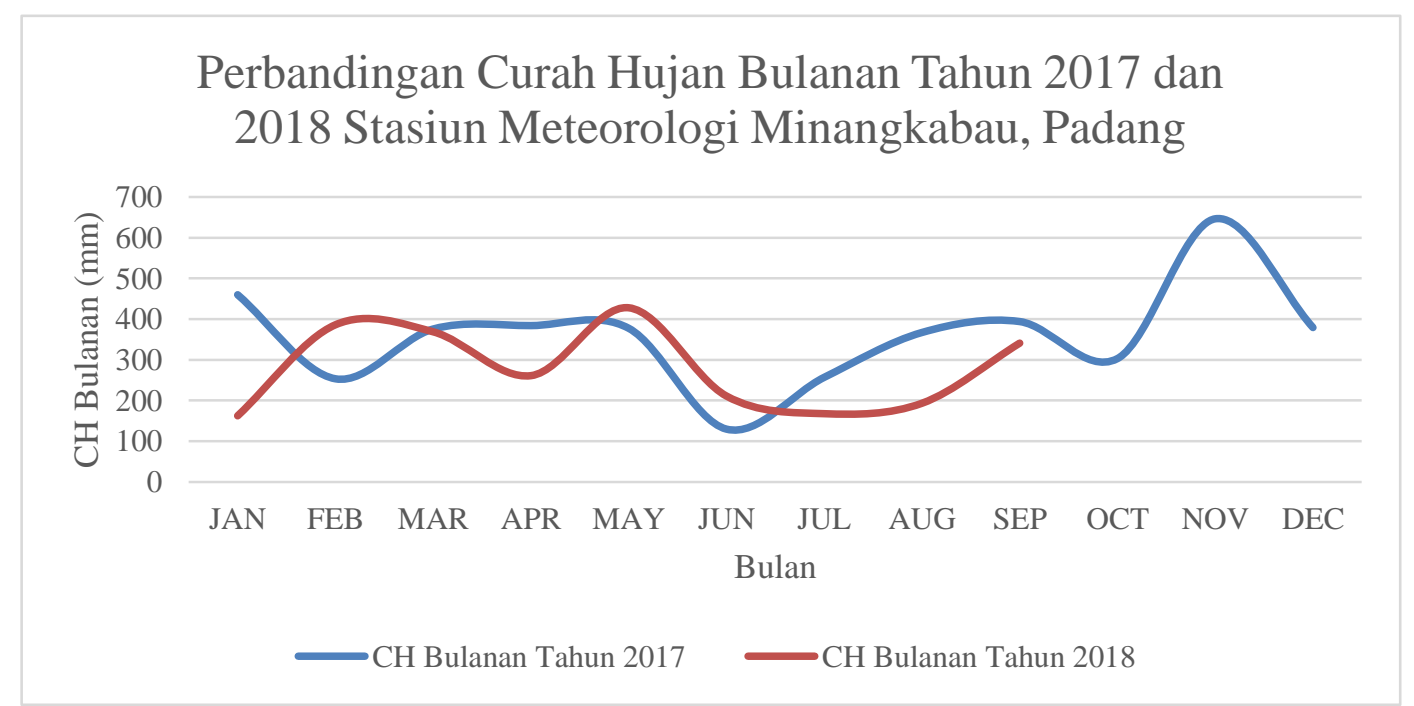

Gambar 5. Grafik Perbandingan Nilai Curah Hujan Bulanan Tahun 2017 dan 2018 Stasiun Meteorologi Minangkabau, Padang 
Grafik di atas menunjukkan perbandingan nilai curah hujan bulanan di tahun 2017 dan 2018 pada Stasiun Meteorologi Minangkabau, Padang. Bulan September di kedua tahun menghasilkan jumlah curah hujan bulanan yang hampir sama nilainya yaitu pada rentang 350 sampai $400 \mathrm{~mm}$. Perbedaan terjadi pada tingkat signifikansi peningkatan curah hujan dari bulan sebelumnya. Peningkatan curah hujan dari Agustus 2017 menuju September 2017 tidak signifikan. Terjadi peningkatan curah hujan yang signifikan dari Agustus 2018 menuju September 2018 berkisar pada nilai $150 \mathrm{~mm}$.

\subsection{Jumlah Hari Hujan (HH) Bulan September Tahun 1982-2018}

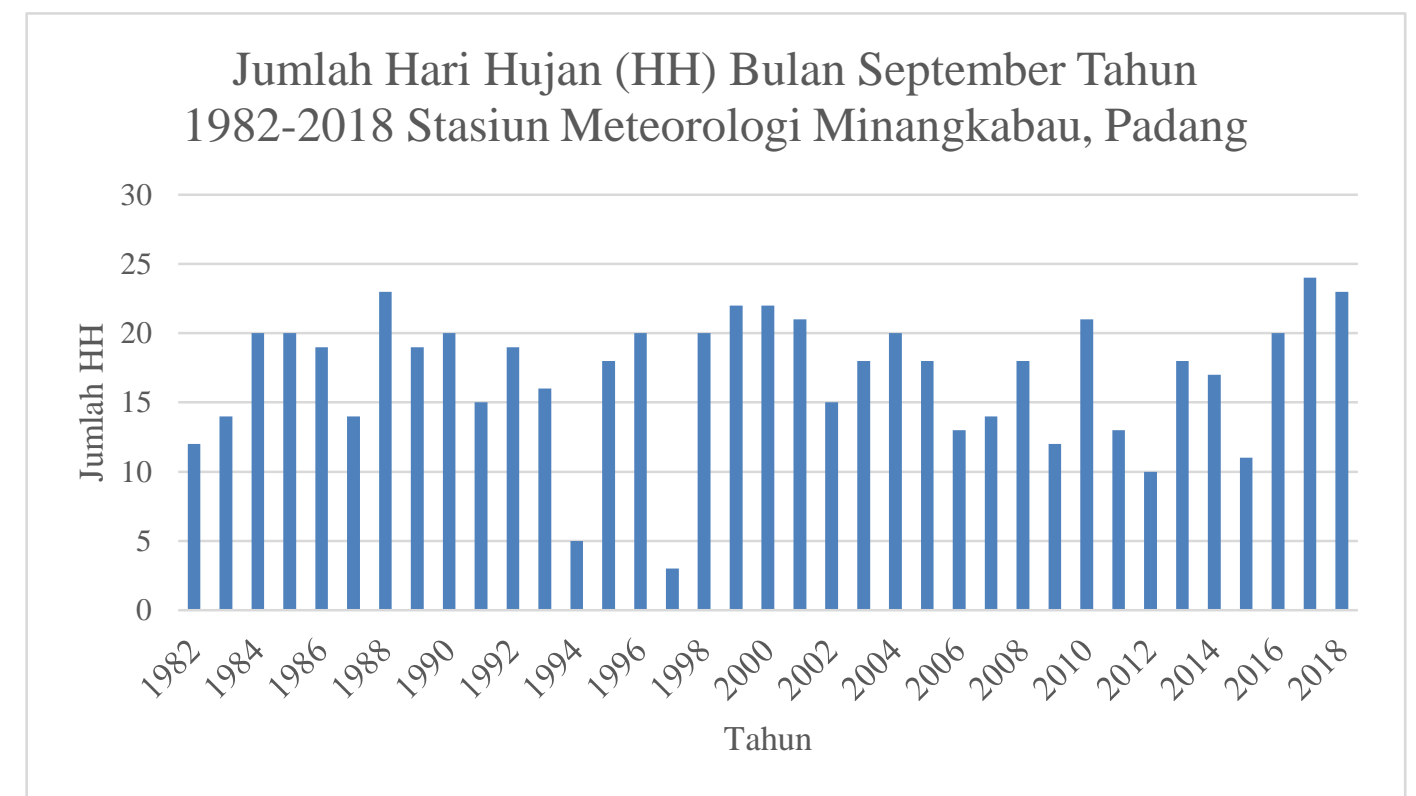

Gambar 6. Grafik Jumlah Hari Hujan Bulan September Tahun 1982-2018 Stasiun Meteorologi Minangkabau, Padang

Dari grafik di atas dapat diketahui jumlah hari hujan selama 30 hari di bulan September dari tahun 1982 sampai 2018. September 2017 dengan jumlah HH 24 dan September 2018 dengan jumlah $\mathrm{HH} 23$ memiliki jumlah hari hujan yang lebih tinggi dari tahun-tahun sebelumnya. Hal tersebut menunjukkan bahwa hampir setiap hari di kedua tahun dalam satu bulan September terdapat hujan baik dalam intensitas ringan sampai lebat. 


\subsection{Citra Satelit Himawari-8 Kanal IR (09 September 2017)}

\subsubsection{Time Series Suhu Puncak Awan di Padang}

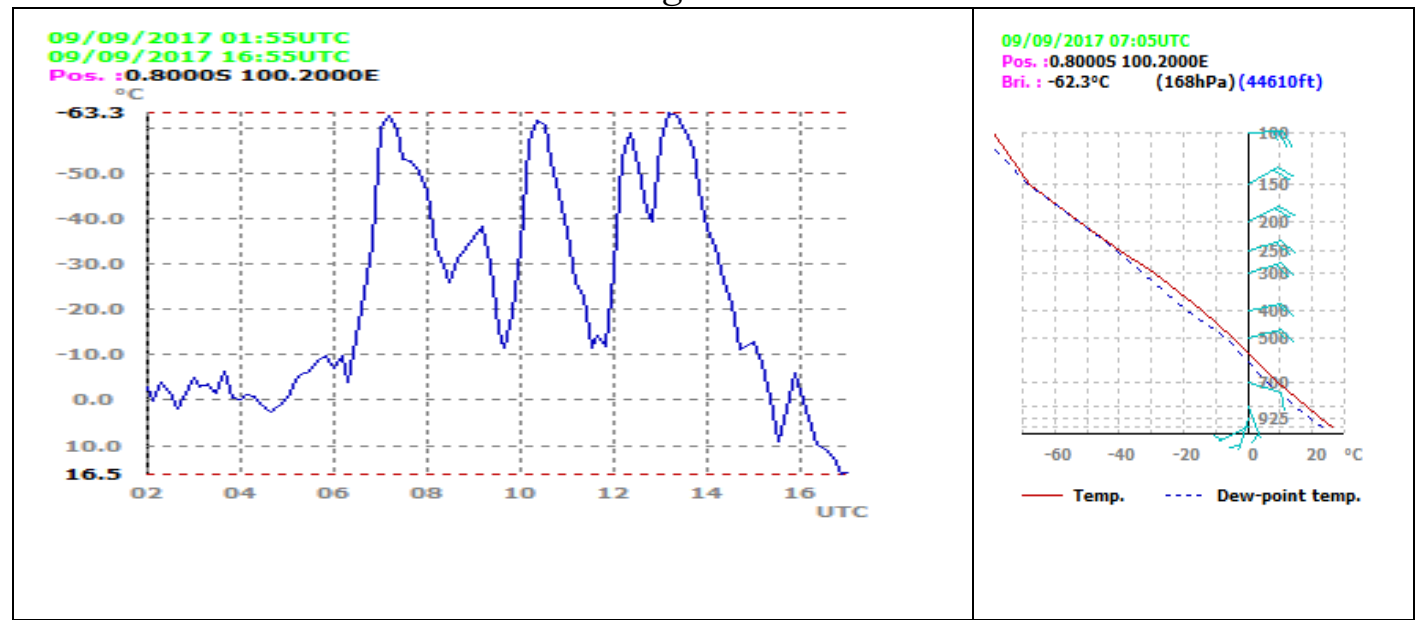

Gambar 7. Time Series Suhu Puncak Awan di Padang pada 9 September 2017

Berdasarkan analisis time series pertumbuhan awan, terlihat bahwa telah terjadi pertumbuhan awan konvektif sekitar pukul 06.00 UTC dengan ditandai mulai naiknya suhu puncak awan di Kota Padang. Terdapat tiga puncak pada time series yang mengindikasikan di titik tersebut terjadi pertumbuhan awan multisel. Aktivitas konvektif terus berlangsung hingga sekitar pukul 13.00 UTC dan suhu puncak awan mencapai $-63.3{ }^{\circ} \mathrm{C}$. Setelah itu awan mengalami fase disipasi sekitar pukul 14.00 UTC dengan ditandai terjadinya kenaikan suhu puncak awan (menghangat) hal ini mengidikasikan awan mulai meluruh dan turun ke lapisan yang lebih rendah.

Sedangkan dari grafik Skew-T lapisan udara atas, terlihat suhu dan titik embun sangat rapat di setiap lapisan. Hal ini mengindikasikan udara bersifat basah dan mendukung terjadinya pembentukan awan.

\subsubsection{Faee Tumbuh}
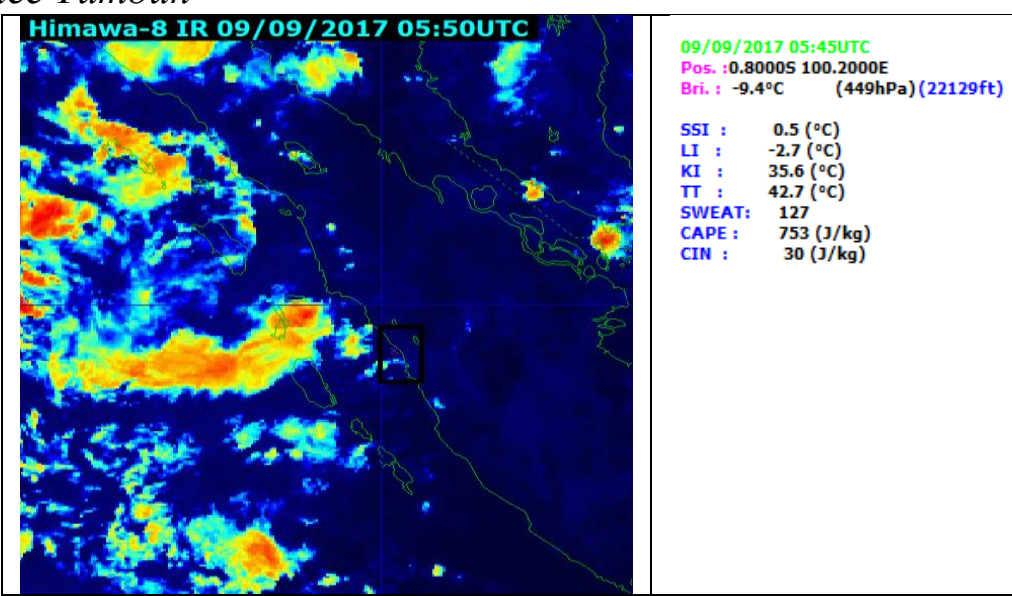

Pada fase tumbuh, dimulai pada pukul 05.50 UTC yang diawali dengan suhu puncak awan sebesar $14,8{ }^{\circ} \mathrm{C}$. Hal ini menandakan awan - awan masih berada di lapisan bawah (hangat). Sedangkan dari data stabilitas udara nilai CAPE sebesar $753 \mathrm{~J} / \mathrm{kg}$ dan nilai SWEAT 127 
termasuk dalam kategori konveksi lemah. Untuk nilai TT Indeks $42,7{ }^{\circ} \mathrm{C}$ dan $\mathrm{K}$ Indeks sebesar $35,6{ }^{\circ} \mathrm{C}$ yang berarti termasuk dalam kategori konveksi sedang. Dari data indeks stabilitas atmosfer tersebut didapatkan bahwa awan - awan konvektif akan berpotensi tumbuh di Kota Padang.

\subsubsection{Fase Matang}

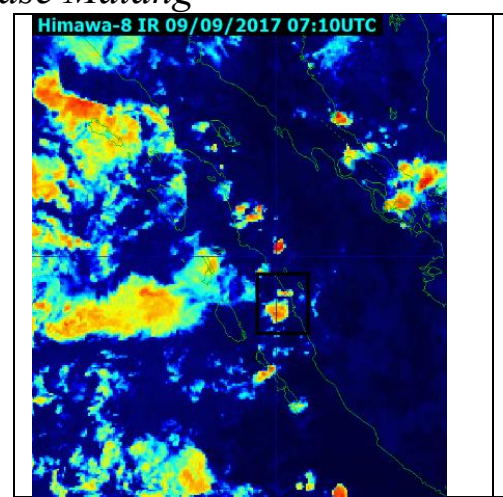

09/09/2017 07:05UTC Po5. : 0.80005 100.2000E Bri. : $-62.3^{\circ} \mathrm{C}$

$(168 \mathrm{hPa})\left(44610 \mathrm{f}\right.$ Bri. : $-61.4^{\circ} \mathrm{C}$

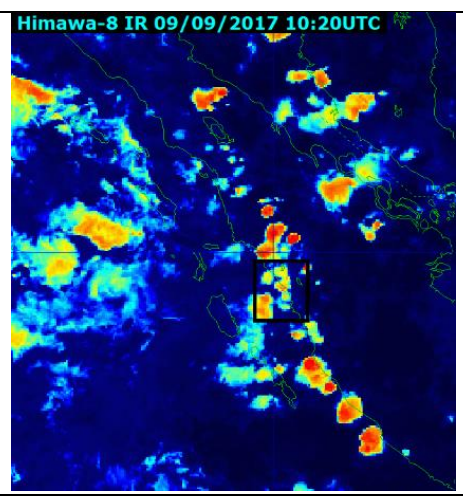

09/09/2017 10:15UTC Po5, : 0.8000S 100.2000E

(171hPa)(44240f Bri. : $-63.3^{\circ} \mathrm{C} \quad(164 \mathrm{hPa})(45060 \mathrm{f}$

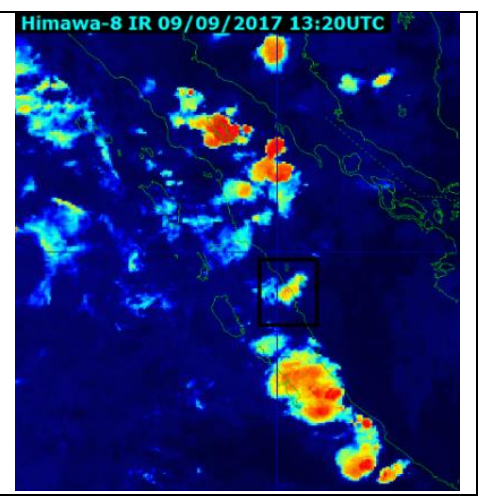

09/09/2017 13:05UTC Po5. : 0.8000S 100.2000E

Berdasarkan kanal infrared pada satelit himawari-8 terlihat gugusan awan berwarna orange hingga merah di sekitar daerah Padang. Warna merah tersebut menunjukkan suhu puncak awan sangat dingin dan kandungan uap air bahkan es yang banyak karena berada di lapisan atas. Pada tanggal 9 September 2017 telihat adanya awan konvektif multisel antara lain terjadi pada pukul: 07.05 UTC, 10.15 UTC, dan 13.05 UTC dengan suhu sekitar $-60{ }^{\circ} \mathrm{C}$. Awan ini terindikasi sebagai awan cumulonimbus yang dapat menghasilkan curah hujan dengan intensitas yang sedang hingga lebat dan downdraft yang kuat.

\subsubsection{Fase Disipasi}

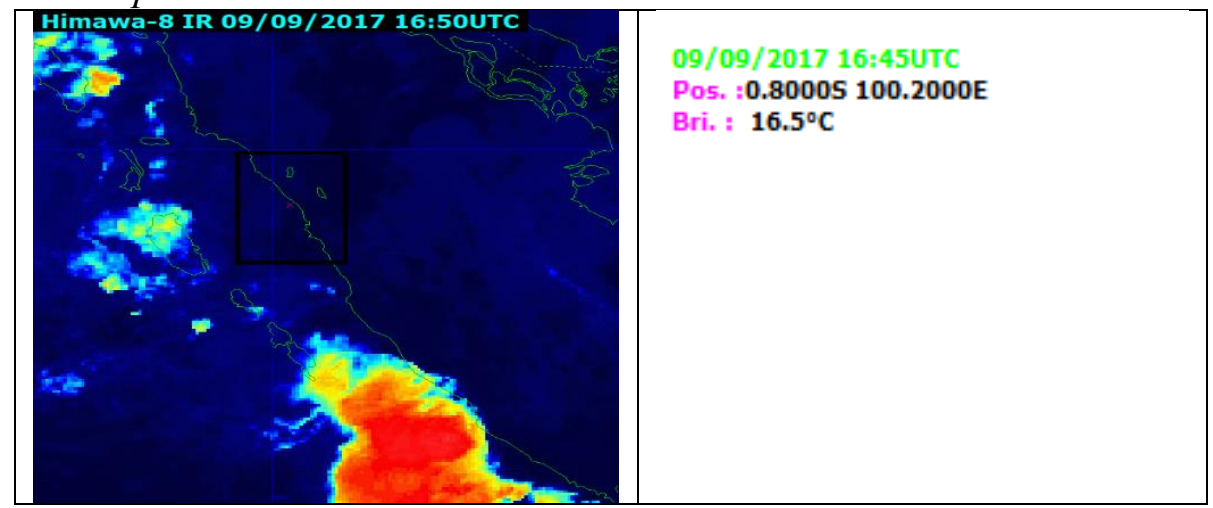

Berdasarkan kanal infrared pada satelit himawari-8 pada pukul 16.50 UTC di daerah Padang sudah tidak terlihat gugusan awan - awan konvektif. Hal itu dapat dilihat suhu puncak awan di titik tersebut sebesar $16.5{ }^{\circ} \mathrm{C}$ yang mengindikasikan hanya terdapat awan - awan rendah (cumulus). 


\subsection{Citra Satelit Himawari-8 Kanal IR (26 September 2018)}

\subsubsection{Time Series Suhu Puncak Awan di Padang}

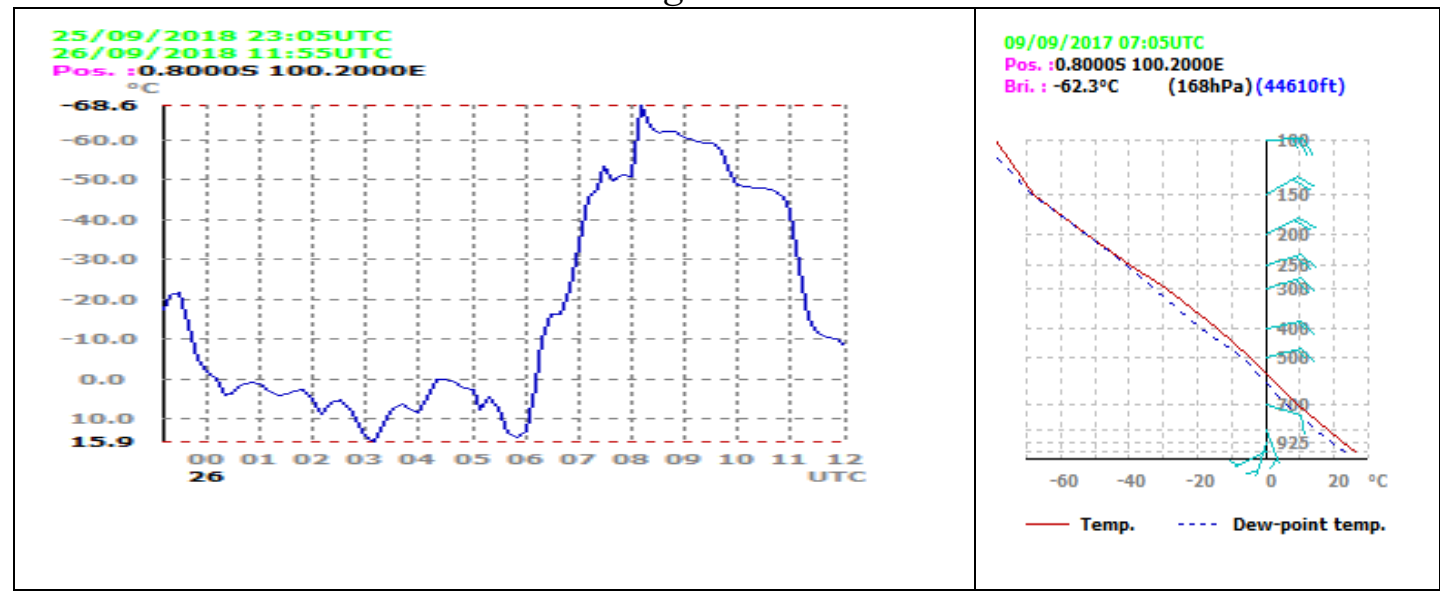

Gambar 8. Time Series Suhu Puncak Awan di Padang pada 26 September 2018

Berdasarkan analisis time series pertumbuhan awan, terlihat bahwa telah terjadi pertumbuhan awan konvektif sekitar pukul 06.00 UTC dengan ditandai mulai naiknya suhu puncak awan di Kota Padang. Aktivitas konveksi terus berlangsung hingga sekitar pukul 08.00 UTC dan suhu puncak awan mencapai $-68,6{ }^{\circ} \mathrm{C}$. Setelah itu awan mengalami fase disipasi sekitar pukul 11.00 UTC dengan ditandai terjadinya kenaikan suhu puncak (menghangat) hal ini mengidikasikan awan mulai meluruh dan turun ke lapisan yang lebih rendah.

Sedangkan dari grafik Skew-T lapisan udara atas, terlihat suhu dan titik embun sangat rapat di setiap lapisan. Hal ini mengindikasikan udara bersifat basah dan mendukung terjadinya pembentukan awan.

\subsubsection{Fase tumbuh}

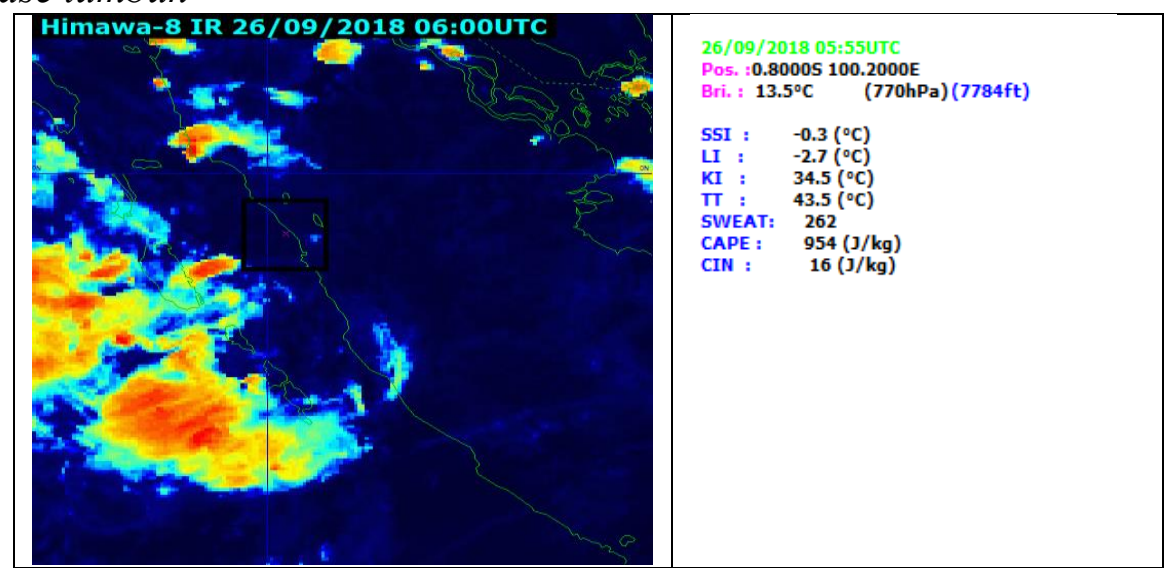

Pada fase tumbuh, dimulai pada pukul 06.00 UTC yang diawali dengan suhu puncak awan sebesar $13,5^{\circ} \mathrm{C}$. Hal ini menandakan awan - awan masih berada di lapisan bawah (hangat). Sedangkan dari data stabilitas udara nilai CAPE sebesar $753 \mathrm{~J} / \mathrm{kg}$ termasuk dalam kategori konveksi lemah. Untuk nilai TT Indeks $43,5^{\circ} \mathrm{C}$ dan $\mathrm{K}$ Indeks sebesar $34,5^{\circ} \mathrm{C}$ yang termasuk dalam kategori konveksi sedang. Sedangkan nilai SWEAT sebesar 262 yang termasuk dalam 
kategori konveksi kuat. Dari data indeks stabilitas atmosfer tersebut didapatkan bahwa awan awan konvektif (cumulonimbus) akan sangat berpotensi tumbuh di Kota Padang.

\subsubsection{Fase Matang}

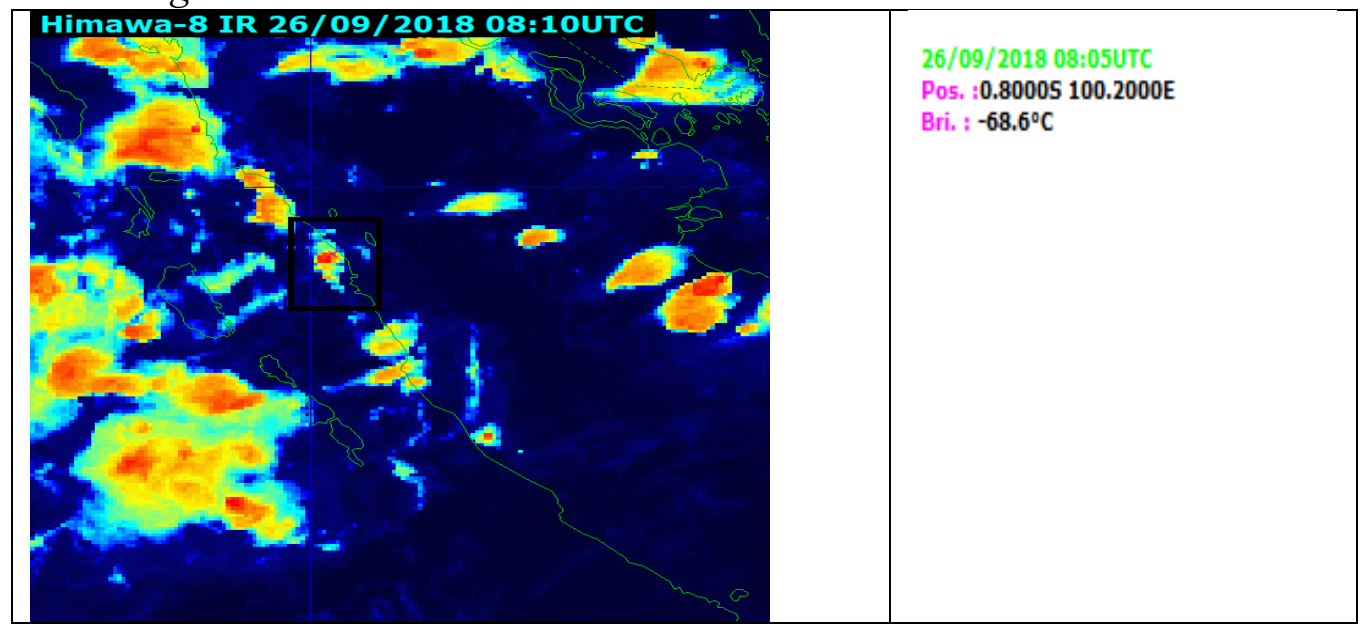

Berdasarkan kanal infrared pada satelit himawari-8 terlihat gugusan awan berwarna orange hingga merah di sekitar daerah Padang. Warna merah tersebut menunjukkan suhu puncak awan sangat dingin yakni $-68,6{ }^{\circ} \mathrm{C}$ dan kandungan uap air bahkan es yang banyak karena berada di lapisan atas. Awan ini terindikasi sebagai awan cumulonimbus yang dapat menghasilkan curah hujan dengan intensitas yang sedang hingga lebat dan downdraft yang kuat.

\subsubsection{Fase Disipasi}

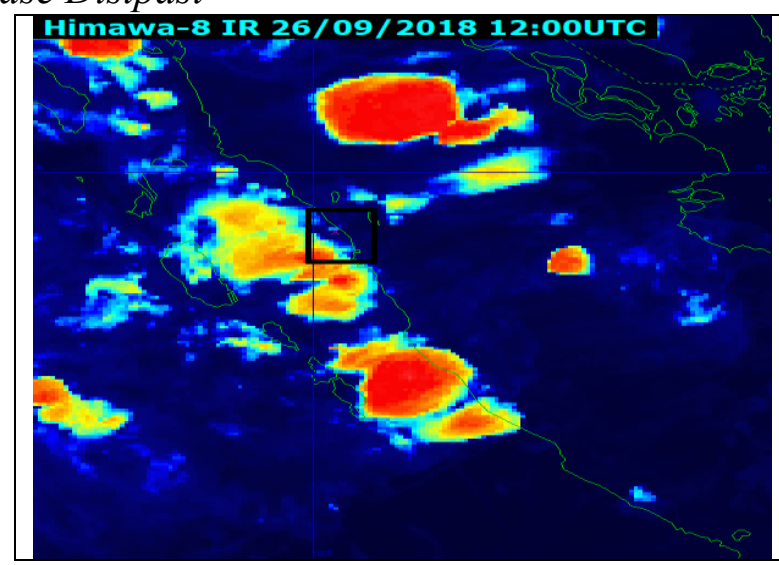

26/09/2018 11:55UTC

Po5. : 0.80005 100.2000E

Bri. : $-8.1^{\circ} \mathrm{C}$

Berdasarkan kanal infrared pada satelit himawari-8 pada pukul 11.55 UTC di daerah Padang sudah tidak terlihat gugusan awan - awan konvektif. Hal itu dapat dilihat dari suhu puncak awan di titik tersebut sebesar $-8.1^{\circ} \mathrm{C}$ yang mengindikasikan hanya terdapat awan awan menengah yakni altocumulus atau altostratus. 


\section{KESIMPULAN}

Dari pembahasan di atas dapat ditarik kesimpulan sebagai berikut:

1. Kota Padang memiliki dua puncak hujan di bulan November dan Maret. Bulan kering terjadi pada Januari hingga Februari (JB) dan Mei hingga Agustus (MJJA). Bulan September merupakan awal dari kondisi basah yang sebelumnya mengalami kondisi kering lebih lama daripada periode kering lainnya dalam satu tahun.

2. September 2017 dan September 2018 berada pada sifat hujan normal dengan presentase 101\% dan 88\%. Peningkatan jumlah curah hujan bulan Agustus $2017 \mathrm{ke}$ September 2017 tidak signifikan yaitu sebesar 27 mm dibandingkan Agustus $2018 \mathrm{ke}$ September 2018 yang signifikan yaitu sebesar $148 \mathrm{~mm}$ jika dibandingkan dengan tahun-tahun sebelumnya. Jumlah hari hujan di bulan September 2017 dan 2018 berturut-turut sebesar 24 dan 23 yang menunjukkan bahwa hampir setiap hari terjadi hujan di bulan-bulan tersebut.

3. Kejadian banjir pada tanggal 9 September 2017 dan 26 September terjadi karena adanya awan konvektif berupa cumulonimbus yang berada di Kota Padang. Awan cumulonimbus tumbuh karena atmosfer bersifat labil dan lembab sehingga mendukung proses konveksi. Dengan adanya downdraft kuat dari awan cumulonimbus yang berada diatas Kota Padang maka menyebabkan hujan lebat dan angin kencang.

\section{SARAN}

1. Untuk mengurangi dampak yang ditimbulkan dari banjir diperlukan adanya penelitian lebih lanjut dan sistem yang terintegrasi dalam membuat peringatan dini cuaca buruk dengan memanfaatkan data remote sensing seperti radar cuaca dan satelit cuaca.

2. Pemanfaatan data klimatologi untuk membuat analisis bulan - bulan dengan curah hujan tinggi dapat digunakan dasar penentuan kebijakan pemerintah setempat untuk mengahadapi dan menanggulangi bencana banjir.

\section{DAFTAR PUSTAKA}

Aldrian, Edvin dan R. Dwi Susanto. (2003). Identification of Three Dominant Rainfall Regions within Indonesia and their Relationship to Sea Surface Temperature. International Journal of Climatology, 23: 1435-1452, doi: 10.1002/joc.950

Budiarti, M., Muslim, M., dan Ilhamsyah, Y. 2012. Studi Indeks Stabilitas Udara Terhadap Prediksi Kejadian Badai Guntur (Badai guntur) di Wilayah Stasiun Meteorologi Cengkareng - Banten. Jurnal Meteorologi dan Geofisika Vol. 13 No. 2.

Davidson NE. 1984. Short-term fluctuations in the Australian monsoon during winter Monex. Monthly Weather Review 112: 1697-1708.

Fadholi, A. Pengolahan Data Citra Satelit MTSAT Menggunakan Aplikasi Sataid (Sattelite Animations And Interactive Diagnosis). Jurnal Informatika dan Komputasi STMIK Indonesia Jakarta. Vol.7 No.1.

Kotaro BESSHO, Kenji DATE, Masahiro HAYASHI, Akio IKEDA. 2016. Journal of the Meteorological Society of Japan. Ser. II. "An Introduction to Himawari-8/9Japan's New-Generation Geostationary Meteorological Satellites”. J-Stage

Tjasyono, Bayong. (2012). Meteorologi Indonesia I: Karakteristik dan Sirkulasi Atmosfer. Penerbit BMKG. 
Wyrtki K. 1956. The rainfall over the Indonesian waters. Verhandelingen, 49. Kementrian Perhubungan Lembaga Meteorologi dan Geofisika, Jakarta. 